SHOCK COMPRESSION PARAMETERS FOR A BORON-LOADED, SILICONE-RUBBER COMPOSITE

\author{
W. H. Gust \\ M. Van Thiel \\ G. R. Gathers
}

July 18,1975

Prepared for U.S. Energy Research \& Development

Administration under contract No. W-7405-Eng-48

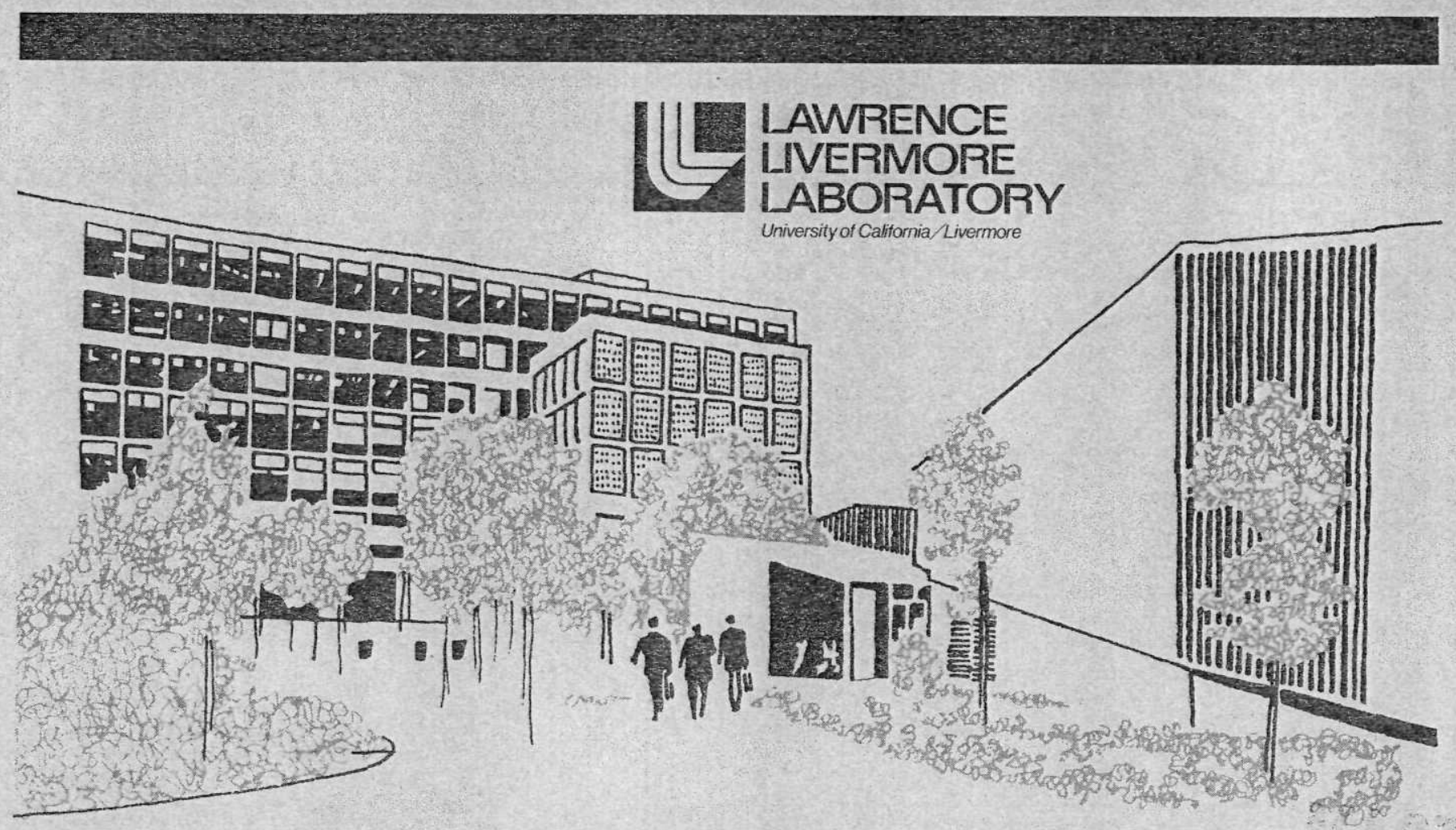




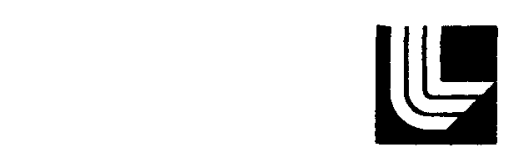

\section{LAWRENCE INERMORE LABORATORY}

University of Caliomia / Livermore, California/ 94550

\section{UCRL-51868 \\ SHOCK COMPRESSION PARAMETERS FOR A BORON-LOADED, SILICONE-RUBBER COMPOSITE}

W. H. Gust

M. Van Thiel

G. R. Gathers

MS. date: July 18, 1975

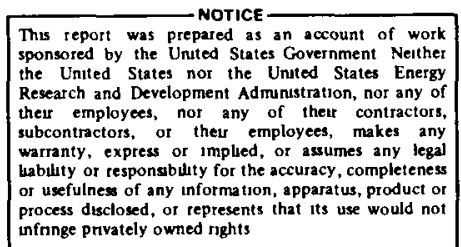




\section{DISCLAIMER}

Portions of this document may be illegible in electronic image products. Images are produced from the best available original document. 


\section{DISCLAIMER}

This report was prepared as an account of work sponsored by an agency of the United States Government. Neither the United States Government nor any agency Thereof, nor any of their employees, makes any warranty, express or implied, or assumes any legal liability or responsibility for the accuracy, completeness, or usefulness of any information, apparatus, product, or process disclosed, or represents that its use would not infringe privately owned rights. Reference herein to any specific commercial product, process, or service by trade name, trademark, manufacturer, or otherwise does not necessarily constitute or imply its endorsement, recommendation, or favoring by the United States Government or any agency thereof. The views and opinions of authors expressed herein do not necessarily state or reflect those of the United States Government or any agency thereof. 


\section{Contents}

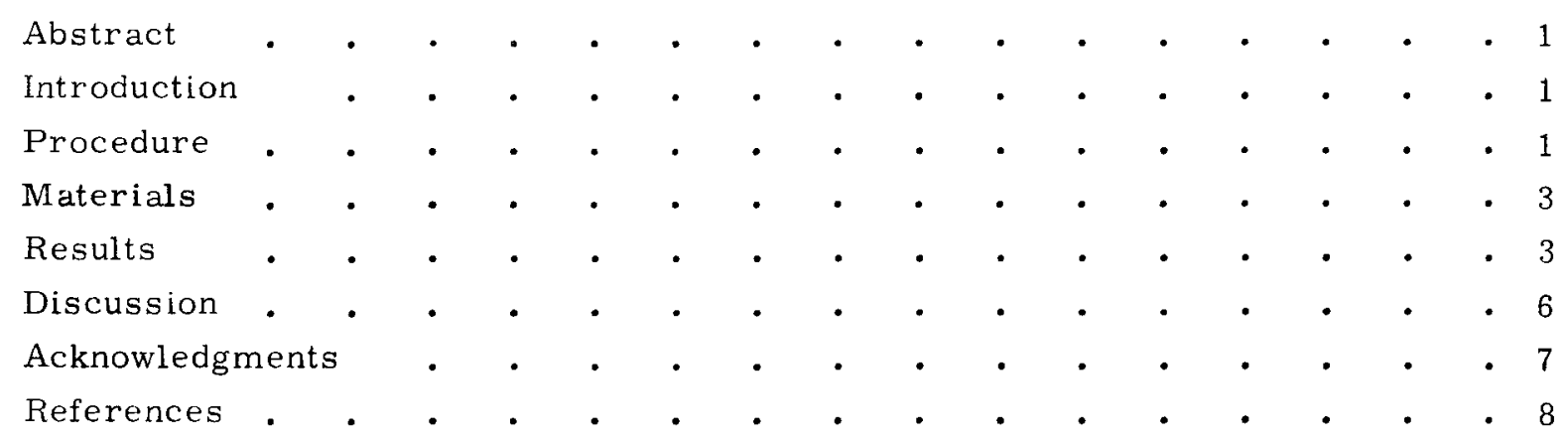




\title{
SHOCK COMPRESSION PARAMETERS FOR A BORON-LOADED, SILICONE-RUBBER COMPOSITE
}

\begin{abstract}
Hugoniot parameters under uniaxialshock-wave-loadıng from 0.03 to $0.6 \mathrm{Mbar}$ are presented for a composite with 70 weight-percent boron loaded in a silıcone-

rubber-matrix. The plot of shock velocity vs particle velocity was found to be nonlinear. Equations which describe fits of the data are presented.
\end{abstract}

\section{Introduction}

The behavior of boron-loaded siliconerubber is of interest because it is an efficient neutron absorber. The siliconerubber provides an easily manufactured matrıx in which a relatively high concentration of the neutron-absorber boron 10 can be uniformly dispersed.

Very little information concerning the equation-of-state properties of loadedsilastics is avallable. Mc Queen et al, ${ }^{1}$ have measured the compression parameters for a quartz-loaded silicone-rubber, RTV-521. Nothıng has been published for boron-loaded silastics.

We describe the results of shockwave experiments on a silicone rubber loaded with $70 \mathrm{w} / 0$ boron These data provide values for some basic parameters needed for hydrodynamic calculations

\section{Procedure}

The explosive systems listed in Table 1 were used to generate plane shock waves producing pressures varying in the composite from about 0.03 to $0.6 \mathrm{Mbar}$. Data at pressures above 300 kbar were obtained using the flash-gap-technique; experiments at pressures less than 300 kbar were done with inclined prisms. Detalled descriptions of the experimental and data-reduction techniques may be found in Refs, 2 and 3. The data are re- ported in terms of pressure and volume where

$$
\begin{aligned}
& \mathrm{P}=\rho_{\mathrm{O}} \mathrm{U}_{\mathrm{S}} \mathrm{U}_{\mathrm{p}} \text { and } \\
& \mathrm{V}=\frac{\mathrm{U}_{\mathrm{S}}-\mathrm{U}_{\mathrm{p}}}{\rho_{\mathrm{O}} \mathrm{U}_{\mathrm{s}}} .
\end{aligned}
$$

The velocity of sound at high pressure was measured by a technıque similar to the lateral relaxation method described 
Table 1. Construction features of the shock generating systems used. (Shock generating systems consisted of a $0.3 \mathrm{~m}$-diam-plane-wave lens with a $0.3 \mathrm{~m}$-right cylinder of high explosive $0.15 \mathrm{~m}$ long unless noted otherwise. All attenuator components were flat and parallel within $5 \mu \mathrm{m}$.)

\begin{tabular}{|c|c|c|c|c|}
\hline System & $\begin{array}{l}\text { High } \\
\text { explosive }\end{array}$ & $\begin{array}{l}\text { Attenuator } \\
\text { material }\end{array}$ & $\begin{array}{c}\text { Component } \\
\text { thickness- }(\mathrm{mm})\end{array}$ & $\begin{array}{l}\text { Pressure } \\
\text { in baseplate } \\
(+5 \%) \text { (kbar) }\end{array}$ \\
\hline A & Baratol $^{a}$ & $\begin{array}{l}\text { Brass } \\
\text { Lucite } \\
\text { Al }\end{array}$ & $\begin{array}{l}25.4 \\
12.7 \\
12.7\end{array}$ & 63 \\
\hline $\mathrm{B}$ & $\begin{array}{l}\text { Pressed } \\
\text { TNT }\end{array}$ & Same as $A$ & Same as $A$ & 100 \\
\hline $\mathrm{C}$ & $\begin{array}{l}\text { Pressed } \\
\text { TNT }\end{array}$ & $\mathrm{Al}$ & 3.2 & 218 \\
\hline $\mathrm{D}$ & $\begin{array}{l}\text { PBX } 9205 \\
\text { (RDX) }\end{array}$ & $\mathrm{Al}$ & 3.2 & 370 \\
\hline $\mathrm{E}$ & $\begin{array}{l}\text { PBX } 9404 \\
\text { (HMX) }\end{array}$ & $\mathrm{Al}$ & 3.2 & 385 \\
\hline $\mathrm{F}$ & $\begin{array}{l}\text { Pressed } \\
\text { TNT }\end{array}$ & $\begin{array}{l}\text { Air } \\
\text { Brass } \\
\text { Air } \\
\text { Al }\end{array}$ & $\begin{array}{r}3.0 \\
4.0 \\
25.4 \\
12.7\end{array}$ & 480 \\
\hline $\mathrm{G}$ & $\begin{array}{l}\text { Pressed } \\
\text { TNT }\end{array}$ & $\begin{array}{l}\text { Air } \\
\text { Monel } \\
\text { Air } \\
\text { Al }\end{array}$ & $\begin{array}{r}3.0 \\
3.0 \\
25.4 \\
12.7\end{array}$ & 530 \\
\hline $\mathrm{H}$ & $\begin{array}{l}\text { PBX } 4205 \\
\text { (RDX) }\end{array}$ & Same as G & Same as G & 680 \\
\hline I & $\begin{array}{l}\text { PBX } 9404 \\
(\text { HMX) }\end{array}$ & Same as G & Same as G & 790 \\
\hline
\end{tabular}

${ }^{a}$ H. E. cylinder was $0.10 \mathrm{~m}$ long.

by Al'tshuler. ${ }^{4}$ In this method it is required that $\overrightarrow{\mathrm{C}}_{*}+\overrightarrow{\mathrm{U}}_{\mathrm{p}}>\overrightarrow{\mathrm{U}}_{\mathrm{s}}$. When the shock passes through the baseplate-sample interface, a sound wave is initiated at the edge of the sample. It proceeds laterally through the compressed sample, and providing $\overrightarrow{\mathrm{C}}_{*}+\overrightarrow{\mathrm{U}}_{\mathrm{p}}>\overrightarrow{\mathrm{U}}_{\mathrm{s}}$, it degrades the shock front in that region, thereby reducing the amplitude of the free-surface motion. The lateral penetration of the sound wave can be measured using a prism. To accomplish this, a flat prism was precisely placed so that the ends of the prism and the sample were aligned.
Hence on the streaking camera record, the edge of the streak located the end of the sample. Further, the prism was long enough so that the shock profile caused by edge effects and a part of the undegraded shock could be observed.

Sound speed at high pressure is related to the shock parameters and the edge curvature through

$$
\mathrm{C}_{*}=\mathrm{U}_{\mathrm{S}}\left[(\tan \alpha)^{2}+\left(\frac{\mathrm{U}_{\mathrm{S}}-\mathrm{U}_{\mathrm{p}}}{\mathrm{U}_{\mathrm{S}}}\right)^{2}\right]^{1 / 2}
$$


where

$$
\tan \alpha=\frac{\mathrm{x}_{2}-\mathrm{x}_{1}}{\mathrm{Mh}} \quad(\text { see Fig. } 1)
$$
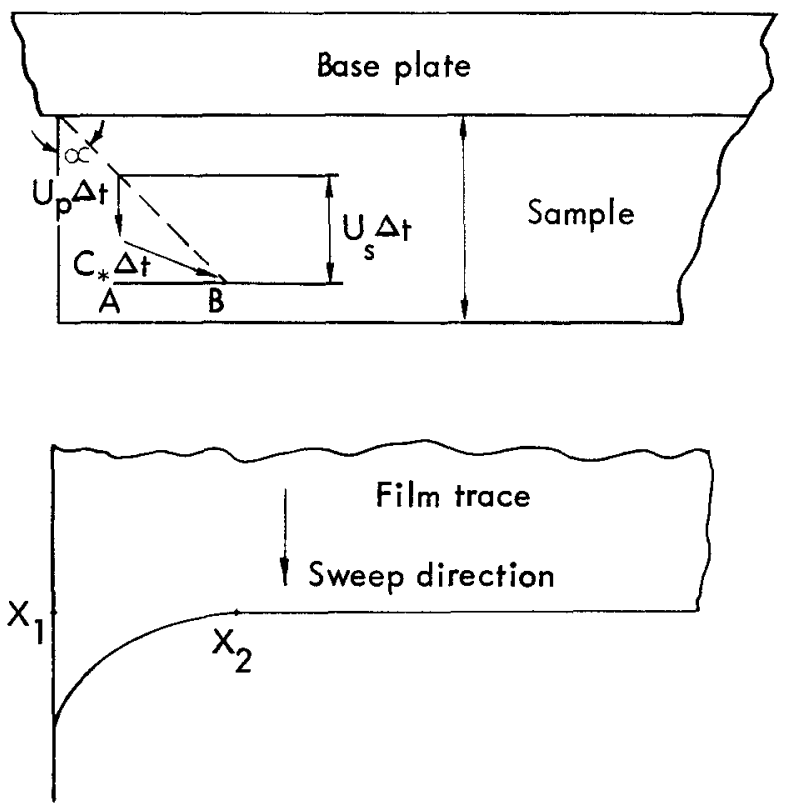

Here $x_{2}$ is the point of inflection on the film record where the undegraded shock profile merges with the curve caused by lateral sound wave penetration from the end of the sample. $x_{1}$ locates the end of the sample; this coincides with the edge of the streak. $M$ is the image-magnification factor and $\mathrm{h}$ is sample thickness.

Fig. 1. Diagram of the relation between $\mathrm{C}_{\mathrm{S}}$ and $\mathrm{U}_{\mathrm{s}}$. From the geometry it is seen that

$$
\begin{aligned}
& \overline{\mathrm{AB}}=\mathrm{U}_{\mathrm{S}} \Delta \mathrm{t} \tan \alpha= \\
& {\left[\left(\mathrm{C}_{*} \Delta \mathrm{t}\right)^{2}-\left(\mathrm{U}_{\mathrm{S}}-\mathrm{U}_{\mathrm{p}}\right)^{2} \Delta \mathrm{t}^{2}\right]^{1 / 2}} \\
& \mathrm{C}_{*}=\mathrm{U}_{\mathrm{S}}\left[(\tan \alpha)^{2}\right. \\
& \left.+\left(\frac{\mathrm{U}_{\mathrm{S}}-\mathrm{U}_{\mathrm{p}}}{\mathrm{U}_{\mathrm{S}}}\right)^{2}\right]^{1 / 2} .
\end{aligned}
$$

\section{Materials}

The samples were manufactured at Lawrence Livermore Laboratory (LLL). Standard rubber milling techniques 5 were used to uniformly disperse $70 \mathrm{w} / \mathrm{o}$ boron powder in a silicone-rubber matrix. The parts are roughly formed by cold molding and then subjected to a vulcanization procedure that included an applied pressure of $0.3 \mathrm{kbar}$ for about $16 \mathrm{hr}$ at $175^{\circ} \mathrm{C}$. The end product should have a density of about $1.81 \mathrm{Mg} / \mathrm{m}^{3}$.

Unfortunately, some of the samples tested were not subjected to the final vulcanization because of an oversight. Consequently there was considerable variation in density from batch to batch. Measured parameters for the low density samples are included, but must be used with caution.

\section{Results}

The Hugoniot parameters are listed in Table 2 and plotted in Figs. 2 and 3 . The results indicate a non-linear relationship between shock and particle velocities. The longitudinal sound speed at one bar was $1.27 \mathrm{~mm} / \mu \mathrm{sec}$; no shear wave was observed. Sound speed in the compressed material was found to be described by $\mathrm{C}_{*}=1.42 \mathrm{U}_{\mathrm{S}}-1.37$. 
Table 2. Data summary.

\begin{tabular}{|c|c|c|c|c|c|c|c|}
\hline$\underset{\text { system }}{\mathrm{H} . \mathrm{E} .}$ & $\begin{array}{c}\text { Free surface } \\
\text { or shock } \\
\text { velocity- } \\
(\mathrm{mm} / \mu \mathrm{sec})\end{array}$ & $\begin{array}{c}\text { Pressure } \\
(\text { Mbar })\end{array}$ & $\begin{array}{r}\text { Initial } \\
\text { density, } \rho_{o} \\
\left(\mathrm{Mg} / \mathrm{m}^{3}\right)\end{array}$ & $\begin{array}{c}\text { Shock } \\
{\text { velocity } U_{S}-}_{(\mathrm{mm} / \mu \mathrm{sec})}\end{array}$ & $\begin{array}{c}\text { Particle } \\
\text { velocity } \mathrm{U}_{\mathrm{p}}- \\
(\mathrm{mm} / \mu \mathrm{sec})\end{array}$ & $\begin{array}{c}\text { Pressure } \\
\text { (Mbar) }\end{array}$ & $\begin{array}{l}\text { Volume } \\
\left(\mathrm{m}^{3} / \mathrm{Mg}\right)\end{array}$ \\
\hline A & $0.83^{\mathrm{a}}$ & 0.068 & 1.701 & 3.45 & $\begin{array}{l}0.61^{\mathrm{b}} \\
0.56^{\mathrm{c}}\end{array}$ & $\begin{array}{l}0.036 \\
0.033\end{array}$ & $\begin{array}{l}0.484 \\
0.492\end{array}$ \\
\hline B & $1.17^{\mathrm{a}}$ & 0.10 & 1.704 & 4.42 & $\begin{array}{l}0.80^{\mathrm{b}} \\
0.78^{\mathrm{c}}\end{array}$ & $\begin{array}{l}0.060 \\
0.059\end{array}$ & $\begin{array}{l}0.481 \\
0.480\end{array}$ \\
\hline C & $2.26^{\mathrm{a}}$ & 0.213 & 1.70 & 6.34 & $\begin{array}{l}1.41^{\mathrm{b}} \\
1.66^{\mathrm{c}, \mathrm{d}}\end{array}$ & $\begin{array}{l}0.152 \\
0.179\end{array}$ & $\begin{array}{l}0.456 \\
0.433\end{array}$ \\
\hline D & $3.04^{\mathrm{a}}$ & 0.310 & 1.705 & 6.66 & $\begin{array}{l}1.90^{\mathrm{b}} \\
2.61^{\mathrm{c}, \mathrm{d}}\end{array}$ & $\begin{array}{l}0.215 \\
0.295\end{array}$ & $\begin{array}{l}0.421 \\
0.358\end{array}$ \\
\hline $\mathrm{E}$ & $3.36^{\mathrm{a}}$ & 0.356 & 1.702 & 7.51 & $\begin{array}{l}2.05^{\mathrm{b}} \\
2.24^{\mathrm{c}, \mathrm{d}}\end{array}$ & $\begin{array}{l}0.262 \\
0.287\end{array}$ & $\begin{array}{l}0.426 \\
0.412\end{array}$ \\
\hline F & $8.30^{\mathrm{e}}$ & 0.507 & 1.765 & 7.79 & $2.69^{\mathrm{b}}$ & 0.368 & 0.372 \\
\hline F & $8.23^{\mathrm{e}}$ & 0.490 & $\begin{array}{l}1.795 f \\
1.625^{f}\end{array}$ & $\begin{array}{l}8.18 \\
7.43\end{array}$ & $\begin{array}{l}2.57^{\mathrm{b}} \\
2.73^{\mathrm{b}}\end{array}$ & $\begin{array}{l}0.378 \\
0.330\end{array}$ & $\begin{array}{l}0.382 \\
0.388\end{array}$ \\
\hline G & $8.44^{\mathrm{e}}$ & 0.540 & 1.799 & 8.35 & $2.74^{\mathrm{b}}$ & 0.411 & 0.374 \\
\hline G & $8.45^{\mathrm{e}}$ & 0.540 & 1.785 & 8.32 & $2.76^{\mathrm{b}}$ & 0.408 & 0.376 \\
\hline $\mathrm{G}$ & $8.64^{\mathrm{e}}$ & 0.585 & $\begin{array}{l}1.788 \mathrm{ff} \\
1.636^{f}\end{array}$ & $\begin{array}{l}8.75 \\
8.30\end{array}$ & $\begin{array}{l}2.88^{\mathrm{b}} \\
3.01^{\mathrm{b}}\end{array}$ & $\begin{array}{l}0.449 \\
0.409\end{array}$ & $\begin{array}{l}0.376 \\
0.389\end{array}$ \\
\hline $\mathrm{H}$ & $8.94^{\mathrm{e}}$ & 0.664 & 1.779 & 9.12 & $3.15^{b}$ & 0.510 & 0.368 \\
\hline $\mathrm{H}$ & $9.15^{\mathrm{e}}$ & 0.720 & $\begin{array}{l}1.775_{f} \\
1.625^{f}\end{array}$ & $\begin{array}{l}9.32 \\
9.0\end{array}$ & $\begin{array}{l}3.37^{\mathrm{b}} \\
3.49^{\mathrm{b}}\end{array}$ & $\begin{array}{l}0.556 \\
0.509\end{array}$ & $\begin{array}{l}0.361 \\
0.377\end{array}$ \\
\hline $\mathrm{H}$ & $9.18^{\mathrm{e}}$ & 0.743 & 1.780 & 9.20 & $3.38^{b}$ & 0.554 & 0.355 \\
\hline I & $9.36^{\mathrm{e}}$ & 0.776 & 1.765 & 9.13 & $3.58^{b}$ & 0.576 & 0.345 \\
\hline I & $9.50^{\mathrm{e}}$ & 0.818 & $\begin{array}{l}1.789 \mathrm{f} \\
1.5666^{\mathrm{f}}\end{array}$ & $\begin{array}{l}9.48 \\
8.80\end{array}$ & $\begin{array}{l}3.65^{\mathrm{b}} \\
3.91^{\mathrm{b}}\end{array}$ & $\begin{array}{l}0.617 \\
0.540\end{array}$ & $\begin{array}{l}0.345 \\
0.354\end{array}$ \\
\hline
\end{tabular}

${ }^{\mathrm{a}}$ Free surface velocity of $\mathrm{Al}$.

${ }^{b_{U_{p}}}$ from impedance match.

${ }_{\mathrm{U}_{\mathrm{p}}}^{\mathrm{p}}=\mathrm{U}_{\mathrm{FS}} / 2$.

${ }^{d}$ Disparity between $U_{p}$ and $U_{F S} / 2$, indicated jetting or spraying of silastics.

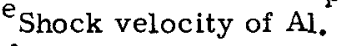

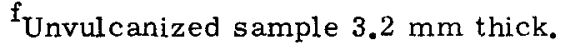

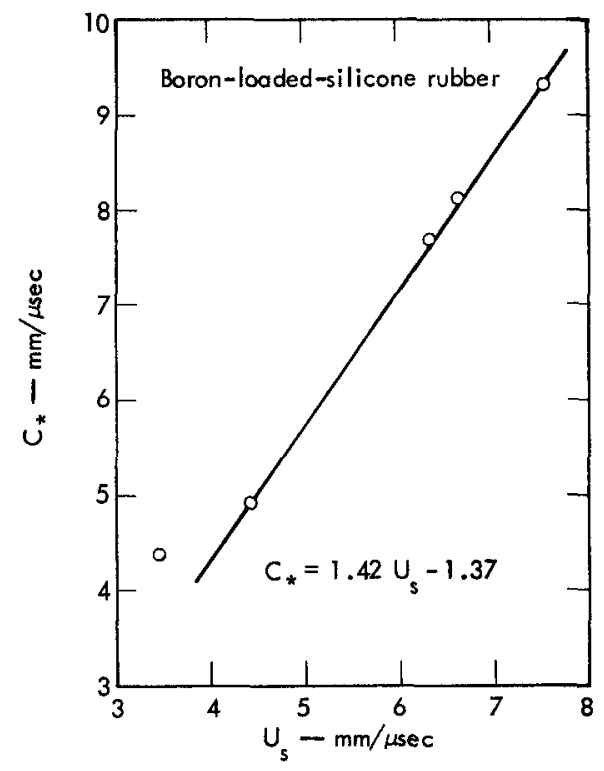

Fig. 2. The plot of $\mathrm{C}_{*}$ (sound speed at pressure) vs $\mathrm{U}_{\mathrm{s}}$ (corresponding shock velocity). The large values for $C_{*}$ indicate that the compressed composite behaves like a brittle material, i.e., more nearly like boron. 


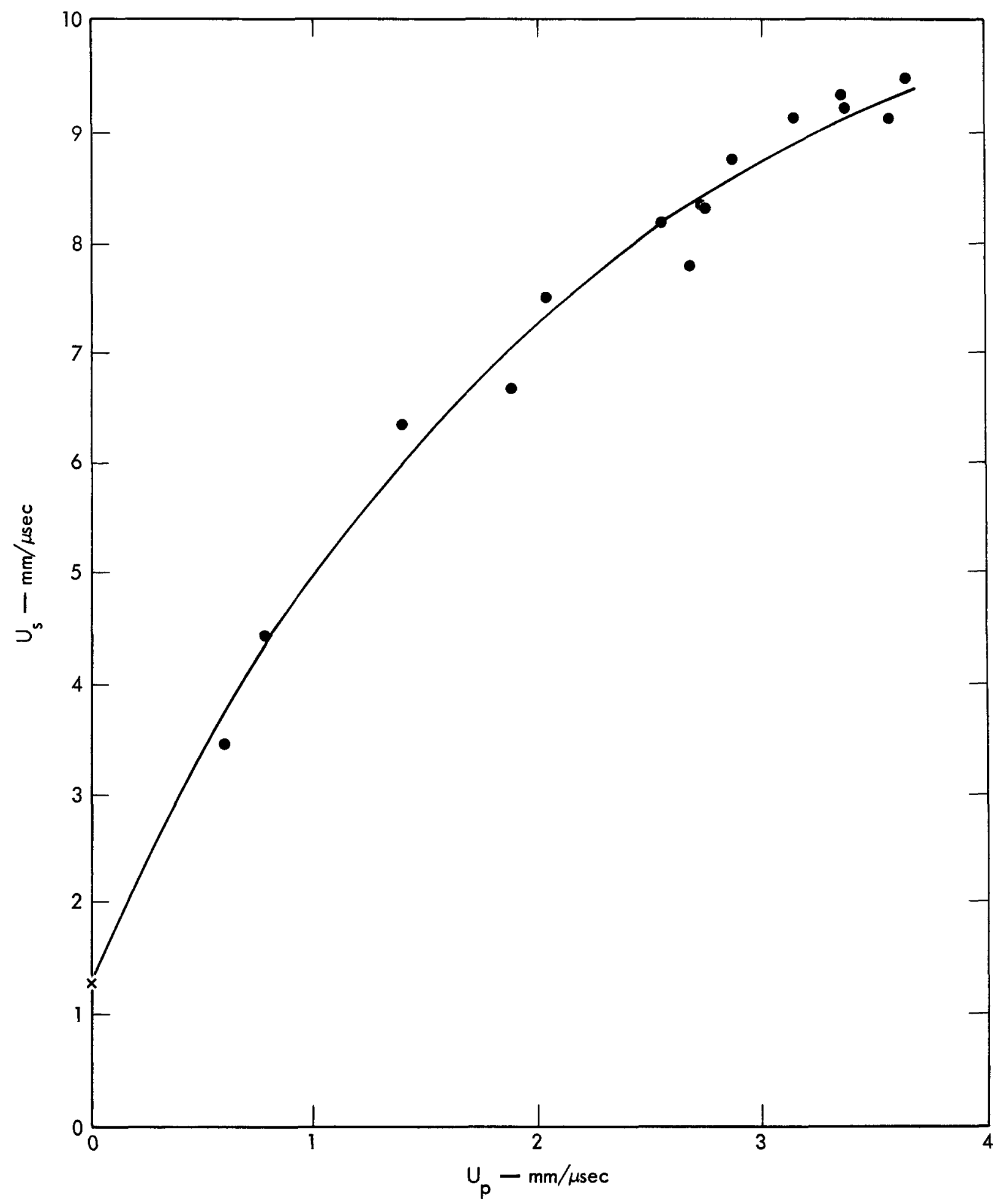

Fig. 3. Least-squares fit to the experimental data. The data display a nonlinear relation between shock velocity and particle velocity. The trace represents a constrained least-square fit to the data, namely

$\mathrm{U}_{\mathrm{s}}=1.27+6.33 \mathrm{U}_{\mathrm{p}}-1.59\left(\frac{\mathrm{U}_{\mathrm{p}}}{\mathrm{U}_{\mathrm{s}}}\right) \mathrm{U}_{\mathrm{p}}+1.37\left(\frac{\mathrm{U}_{\mathrm{p}}}{\mathrm{U}_{\mathrm{s}}}\right)^{2} \mathrm{U}_{\mathrm{p}}$ 


\section{Discussion}

The results indicate that boron-rubber exhibits several unusual features under shock loading. First, it is noted that values obtained for shock velocity indicate that the boron component of the compressed composite immediately dominates shock propagation. Shock velocities ranging from 4 to $9.5 \mathrm{~mm} / \mu \mathrm{sec}$ are obtained at relatively low pressures. This is in contrast with the longitudinal sound speed at $1 \mathrm{bar}, 1.27 \mathrm{~mm} / \mu \mathrm{sec}$, where propagation velocity is more consistent with

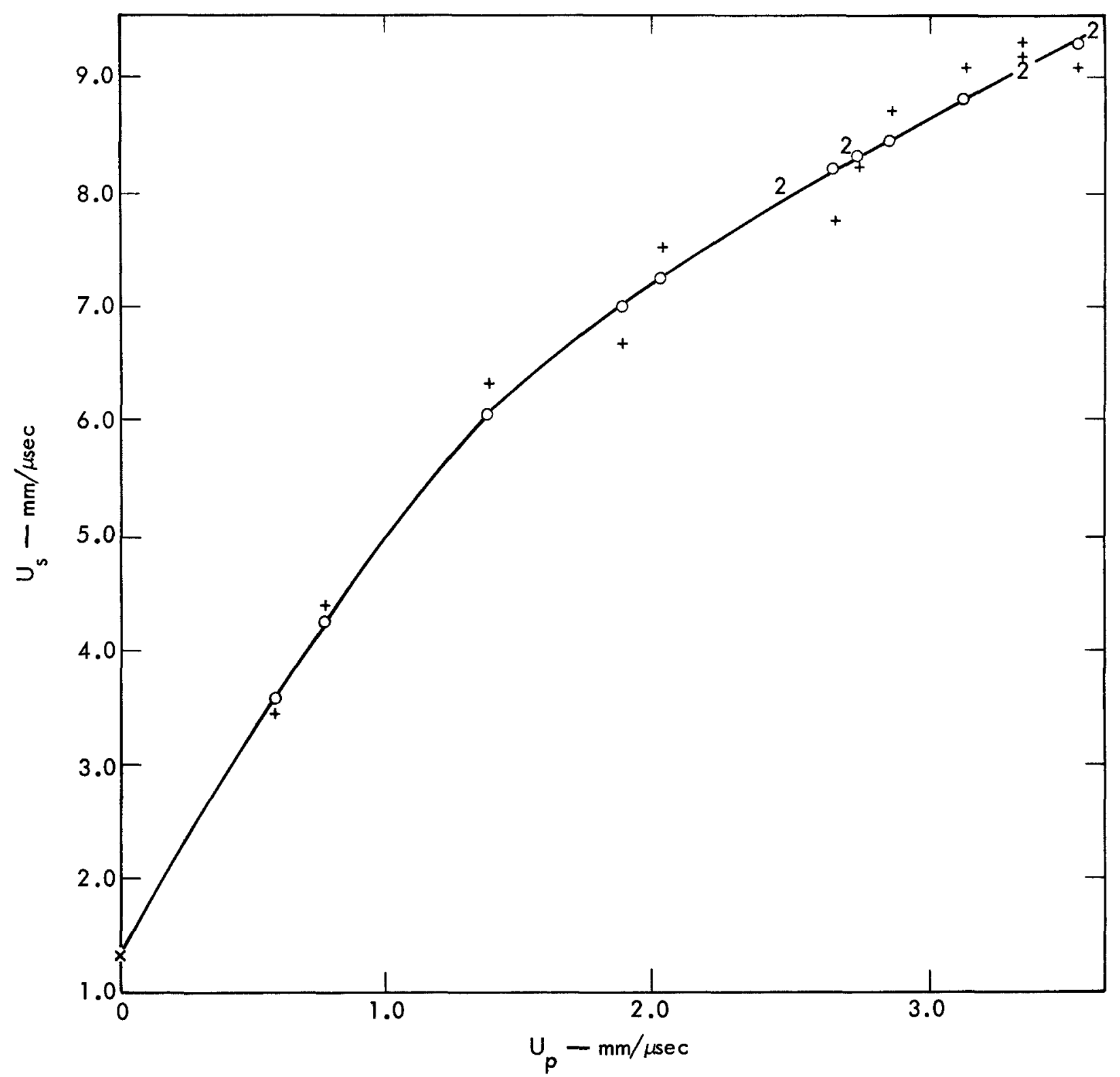
Fig. 4. Fit to Van Thiel's representation of the data. Here the same $\left(U_{s^{\prime}} U_{p}\right)$ data
is fit to an equation

$$
U_{\mathrm{S}}=1.27+5.62\left(\frac{\mathrm{U}_{\mathrm{p}}^{1.55}}{1+\mathrm{U}_{\mathrm{p}}^{1.55}}\right)+0.887 \mathrm{U}_{\mathrm{p}} \text {. }
$$


that of rubber. In other words, the material initially behaves like rubber, but under small pressure it immediately exhibits shock propagation qualities more like those of a brittle substance. Further, film traces from inclined prism experiments indicated high velocity jetting or spraying of one component, probably the silastic.

Additional evidence of anamolous behavior is obtained from the measurement of sound speed under compression. Figure 2 shows that sound speed in the compressed material immediately attains values greater than $5 \mathrm{~mm} / \mu \mathrm{sec}$. Note that the $\left(\mathrm{C}_{*}, \mathrm{U}_{S}\right)$ curve does not intercept at the value for $\mathrm{C}_{\mathrm{L}}$ at one bar, namely $1.27 \mathrm{~mm} / \mu \mathrm{sec}$, but at a negative value.

The least-squares fit coefficients for Grover's scheme ${ }^{6}$ for obtaining a representation of non-linear $\left(U_{s}, U_{p}\right)$ data are:

$$
\begin{aligned}
\mathrm{U}_{\mathrm{S}}=1.27+6.33 \mathrm{U}_{\mathrm{p}}-1.59\left(\frac{\mathrm{U}_{\mathrm{p}}}{\mathrm{U}_{\mathrm{s}}}\right) \mathrm{U}_{\mathrm{p}} \\
+1.37\left(\frac{\mathrm{U}_{\mathrm{p}}}{\mathrm{U}_{\mathrm{s}}}\right)^{2} \mathrm{U}_{\mathrm{p}}
\end{aligned}
$$

This constrained least-squares fit, based upon relative error is shown as the curve in Fig. 3 .

Van Thiel has suggested that the initial non-linear portion of the $\left(U_{s}, U_{p}\right)$ curve can be corrected by introducing an additional factor $A\left(U_{p}^{n} / 1+U_{p}^{n}\right)$ in the usual linear equation. The optimum fit to the data for this type of representation (Fig. 4) was found to be $\mathrm{U}_{\mathrm{S}}=1.27+5.62\left(\frac{\mathrm{U}_{\mathrm{p}}^{1.55}}{1+\mathrm{U}_{\mathrm{p}}^{1.55}}\right)+0.887 \mathrm{U}_{\mathrm{p}}$

The standard deviation for $U_{S}$ was 0.24 and the deviations for $\mathrm{A}$ and $\mathrm{S}$ were 0.48 and 0.14 . This representation assumes continued linearity at very high pressures.

\section{Acknowledgments}

We wish to thank W. D. Barrowman for technical assistance, R. W. Brown, L. F. Simmons and A. Donnici for aid at the high-explosives test site, R. P. Brown for obtaining the materials, and D. I. Steinberg and Mark Wilkins for support. 


\section{References}

1. R. G. Mc Queen, S. P. Marsh, J. W. Taylor, J. N. Fritz and W. J. Carter, High Velocity Impact Phenomena, Ray Kinslow, Ed. (Academic Press, New York, 1970) p. 356.

2. W. H. Gust and E. B. Royce, J. Appl. Phys. 42, 1897 (1971).

3. W. H. Gust and E. B. Royce, Phys. Rev. B 15, 8, 3595 (1973).

4. L. V. Al'tshuler, Usp. Fiz. Nauk 85, 197 (1965). [Eng. Trans. Soviet Phys, USPEKHI 8, $52(1965)$ ].

5. Introduction to Rubber Technology, Maurice Morton, Ed. (Reinhold Publishing Corp., New York, New York) Ch. 16.

6. R. Grover, Lawrence Livermore Laboratory Internal Memorandum, STN 299 (1972). Readers outside the Laboratory who desire further information on LLL internal documents should address their inquiries to the Technical Information Department, Lawrence Livermore Laboratory, Livermore, California 94550.

$\mathrm{TAL} / \mathrm{bl} / \mathrm{edas}$ 